\title{
Affective Factors in Foreign Language Education: The Role of Anxiety
}

\section{Rachid Elkhayma}

Doctoral student in Ibn Tofail University, in Kenitra, Morocco.

High School EFL teacher and instructor in Morocco.

\begin{abstract}
This study investigates the role of affective factors in language education. Specifically, it studies the influence of anxiety on EFL learning. It examines students' speaking and test anxieties and whether it prevents them from engaging in the classroom communication activities or not. The study was carried out in a Moroccan EFL class. Twenty students participated in the study. They answered a closedended lickert-scale questionnaire that gathered data about the target phenomenon. The results showed that students' level and feeling of anxiety differed from an educational and instructional situation to another. They also showed that most Moroccan EFL students have low anxiety levels and feelings towards English, because their attitudes towards it are generally positive.
\end{abstract}

Keywords - anxiety, foreign language learning, speaking, affective factors.

\section{INTRODUCTION}

Foreign language learning faces many challenges related to the student, the teacher, the course content or the curriculum as a whole. One of the recurrent problems students face in EFL learning is the impact of affective factors, as found in Skehan (1991), such as anxiety, motivation, attitude, self-esteem, age, attitude, and so on and so forth. These affective factors have been the focus of a significant body of research for many years now. They were studied by several researchers, like Stevick (1989),Dörnyei (2001), Day \&Lee (2011), Chemi \& Lund (2015) and Bellocchi et al. (2017).

As maintained in Horwitz et al. (1986) and Young (1986), one of such affective factors that has a direct and unequivocal influence on learning a foreign language, and education at large, is anxiety. It is triggered by feelings of nervousness and stress in class, and it is widely common among language learners; in the sense that it is highly unlikely that a foreign language learner does not experience learning anxiety. This implies that almost all FL students feel anxious at a certain time about whether they can speak the target FL in class without thinking too much about making mistakes or feeling embarrassed in front of their classmates. It is an indication, then, that there is a close relationship between anxiety and learning a foreign language or a second language.

\section{FRAMEWORK}

This study was inspired by the research conducted by Horwitz et al., (1986) about anxiety in foreign language education. Anxietyis a "major obstacle to be overcome in learning to speak another language" (p. 125). According to Horwitz et al. (1986), researchers identified several anxieties related to foreign language learning: 'communication apprehension', 'test anxiety' and 'fear of negative evaluation'. Copious psychological and educational issues may certainly be the causes for such a feeling. Foreign language learners may feel strange, awkward or uncomfortable speaking the language. This is particularly for young learners who are too keen on their image before their peers, and who are in constant need for acceptance and recognition by their friends and classmates. This is what makes them feel embarrassed when they make mistakes or unhappy when the teacher keeps correcting them all the time. The situation can get worse if the learner cannot harbor a feel of estrangement towards the target language, for they may find problems understanding or pronouncing the foreign language. Stevick (1989) cites the example of Arabic as a foreign language learner who was tutored with 'printed material' to on Arabic pronunciation, whose "main value was that having them relieved her anxiety, and so allowed her mind to accept and work with the incoming sounds more readily" (p. 121). Besides, foreign language learners may have a constant feeling of 
apprehension about failing their FL test, which invariably puts them under pressure and develops a feeling of anxiety.

\section{METHODOLOGY}

\section{$\underline{\text { Participants }}$}

20 EFL students participated in the study. All the students belonged to the third grade level, and they studied in the same class. Twelve participants were females, while eight were male students.

\section{Type of data collection}

A lickert-scale closed-ended questionnaire, as recommended by Creswell (2012), was used to collect data from students. It was built on five scales: agree; strongly agree; undecided; disagree; strongly disagree. It was based on and adapted from the Foreign Language Classroom Anxiety Scale (FLCAS) developed by Horwitz e al., (1986). The questionnaires were distributed to students in their English as a foreign language classroom, in which they responded to them. The students were asked to check the corresponding response that best suited their opinions and feelings towards anxiety in the foreign language classroom.

The questionnaire statements identified students' feelings of anxiety or relaxation in their EFL class. There were 14 statements that addressed the topic of the study. They are as follows:
- I feel confident when I speak in my foreign language class;

- I feel excited to speak in my English class;

- I don't feel nervous when I make mistakes;

- I feel I cannot speak in my English class;

- I feel tense when my teacher starts to point at students for answers;

- I feel nervous when I don't understand what the teacher is talking about;

- I feel relaxed in my class even if I don't understand what the teacher is saying;

- I usually feel absent-minded in my foreign language class;

- I tremble when I speak without preparation;

- I feel nervous whenever I step in my English class;

- I always think about failing my English class;

- I feel embarrassed when I make mistakes;

- I always think that others are better than me;

- I feel upset when my teacher keeps correcting me all the time.

Type of data analysis

The SPSS statistical software package was used to analyze the obtained data from closed-ended questionnaires.

\section{RESULTS}

Table1: I feel I cannot speak in my English class

\begin{tabular}{|l|r|r|r|r|}
\hline & Frequency & Percent & Valid Percent & $\begin{array}{c}\text { Cumulative } \\
\text { Percent }\end{array}$ \\
\hline agree & 3 & 15,0 & 15,0 & 15,0 \\
undecided & 4 & 20,0 & 20,0 & 35,0 \\
Valid disagree & 12 & 60,0 & 60,0 & 95,0 \\
& 1 & 5,0 & 5,0 & 100,0 \\
stronglydisagree & 20 & 100,0 & 100,0 & \\
Total & & &
\end{tabular}

Table 1 shows that more than half of the class believed that they can speak and interact in the foreign language classroom. 4 students were undecided about whether they could use English to interact in class. Only 3 students felt anxious about about their ability to talk in English in their FL classroom. 
Table 2: I don't feel nervous when I make mistakes in my English class

\begin{tabular}{|l|r|r|r|r|}
\hline & Frequency & Percent & Valid Percent & $\begin{array}{c}\text { Cumulative } \\
\text { Percent }\end{array}$ \\
\hline agree & 10 & 50,0 & 50,0 & 50,0 \\
Stronglyagree & 1 & 5,0 & 5,0 & 55,0 \\
Valid undecided & 4 & 20,0 & 20,0 & 75,0 \\
& 5 & 25,0 & 25,0 & 100,0 \\
disagree & 20 & 100,0 & 100,0 & \\
Total & & & & \\
\hline
\end{tabular}

Table 2 reveals that half of the class revealed that they do not feel nervous when they make mistakes in their English class, whereas 4 students were undecided about their opinions. 5 students expressed anxiety over this issue, saying they do feel nervous when they make mistakes.

Table 3: Ifeel tense when my teacher starts to point at students for answers

\begin{tabular}{|l|r|r|r|r|}
\hline & Frequency & Percent & Valid Percent & $\begin{array}{c}\text { Cumulative } \\
\text { Percent }\end{array}$ \\
\hline agree & 7 & 35,0 & 35,0 & 35,0 \\
undecided & 5 & 25,0 & 25,0 & 60,0 \\
Valid disagree & 7 & 35,0 & 35,0 & 95,0 \\
& 1 & 5,0 & 5,0 & 100,0 \\
stronglydisagree & 20 & 100,0 & 100,0 & \\
Total & & & & \\
\hline
\end{tabular}

Table 3 explains that different opinions were revealed in responding to the statement 'I feel tense when the teacher starts to point at students to answer'. 7 students showed agreement, while 7 others showed disagreement with the statement. 5 others were unsure about their opinions, whereas only 1 student responded with strong disagreement.

Table 4: I feel nervous when I don't understand what the teacher is saying

\begin{tabular}{|c|c|c|c|c|c|}
\hline & & Frequency & Percent & Valid Percent & $\begin{array}{c}\text { Cumulative } \\
\text { Percent }\end{array}$ \\
\hline \multirow{4}{*}{ Valid } & agree & 10 & 50,0 & 50,0 & 50,0 \\
\hline & undecided & 4 & 20,0 & 20,0 & 70,0 \\
\hline & disagree & 6 & 30,0 & 30,0 & 100,0 \\
\hline & Total & 20 & 100,0 & 100,0 & \\
\hline
\end{tabular}

Table 4 demonstrates that while half of the group (10 out of 20 students) was nervous about not being able to understand the teacher's talk, 6 others were not nervous at all. 4 other students were not sure about their opinions. 
Table 5: I usually feel absent-minded in my English class

\begin{tabular}{|c|c|c|c|c|c|}
\hline & & Frequency & Percent & Valid Percent & $\begin{array}{c}\text { Cumulative } \\
\text { Percent }\end{array}$ \\
\hline \multirow{4}{*}{ Valid } & agree & 5 & 25,0 & 25,0 & 25,0 \\
\hline & undecided & 8 & 40,0 & 40,0 & 65,0 \\
\hline & disagree & 7 & 35,0 & 35,0 & 100,0 \\
\hline & Total & 20 & 100,0 & 100,0 & \\
\hline
\end{tabular}

Table 5 shows that students expressed precarious opinions towards whether they feel absent minded in their English class. 5 of them revealed that they felt absent minded, while 7 others did not feel absent minded. Surprisingly enough, 8 students were not sure if they ever were absent minded during the English class.

Table 6: I feel relaxed in my class even if I don't understand what the teacher is saying

\begin{tabular}{|c|c|c|c|c|c|}
\hline & & Frequency & Percent & Valid Percent & $\begin{array}{c}\text { Cumulative } \\
\text { Percent }\end{array}$ \\
\hline \multirow{5}{*}{ Valid } & Agree & 12 & 60,0 & 60,0 & 60,0 \\
\hline & stronglyagree & 1 & 5,0 & 5,0 & 65,0 \\
\hline & Undecided & 3 & 15,0 & 15,0 & 80,0 \\
\hline & Disagree & 4 & 20,0 & 20,0 & 100,0 \\
\hline & Total & 20 & 100,0 & 100,0 & \\
\hline
\end{tabular}

Table 6 reveals that more than half of the group (12 students out of 20) showed agreement that they felt relaxed in class even if they did not understand the teacher's talk, whereas only 4 students expressed disagreement with that statement. Besides, 3 others were undecided about their responses, while 1 was very anxious about not being able to feel relaxed, as he / she could not understand the teacher's talk.

Table 7: I tremble when I speak without preparation

\begin{tabular}{|c|c|c|c|c|c|}
\hline & & Frequency & Percent & Valid Percent & $\begin{array}{c}\text { Cumulative } \\
\text { Percent }\end{array}$ \\
\hline \multirow{4}{*}{ Valid } & Agree & 8 & 40,0 & 40,0 & 40,0 \\
\hline & Undecided & 3 & 15,0 & 15,0 & 55,0 \\
\hline & Disagree & 9 & 45,0 & 45,0 & 100,0 \\
\hline & Total & 20 & 100,0 & 100,0 & \\
\hline
\end{tabular}

Table 7 shows that eight students think that they tremble when they speak English without preparation, while 9 others show that they are not anxious at all about using English, even if they may not be well prepared. 3 other students are undecided about whether they feel nervous or not. 
Table 8: I feel nervous whenever I step in my English class

\begin{tabular}{|l|r|r|r|r|}
\hline & Frequency & Percent & Valid Percent & $\begin{array}{c}\text { Cumulative } \\
\text { Percent }\end{array}$ \\
\hline Agree & 3 & 15,0 & 15,0 & 15,0 \\
Valid disagree & 1 & 5,0 & 5,0 & 20,0 \\
undecided & 11 & 55,0 & 55,0 & 75,0 \\
stronglydisagree & 5 & 25,0 & 25,0 & 100,0 \\
Total & 20 & 100,0 & 100,0 & \\
\hline
\end{tabular}

Table 8 illustrates that more than half of the students did not feel nervous when they get into their English class, and 5 other students responded with strong disagreement that they do not have anxiety at all when they step in the English classroom. Moreover, only 3 students felt anxious once they arrive at their English class.

Table 9: I'm always thinking about failing my English class

\begin{tabular}{|c|c|c|c|c|c|}
\hline & & Frequency & Percent & Valid Percent & $\begin{array}{c}\text { Cumulative } \\
\text { Percent }\end{array}$ \\
\hline \multirow{6}{*}{ Valid } & Agree & 9 & 45,0 & 45,0 & 45,0 \\
\hline & stronglyagree & 1 & 5,0 & 5,0 & 50,0 \\
\hline & Undecided & 5 & 25,0 & 25,0 & 75,0 \\
\hline & Disagree & 4 & 20,0 & 20,0 & 95,0 \\
\hline & stronglydisagree & 1 & 5,0 & 5,0 & 100,0 \\
\hline & Total & 20 & 100,0 & 100,0 & \\
\hline
\end{tabular}

Table 9 shows that almost half of the class felt anxious about failing their English class, while 5 other students did not think about that at all. In addition, 5 other students were not sure if they always think about failing their English test or not.

Table 10: I feel embarrassed when I make mistakes

\begin{tabular}{|l|r|r|r|r|}
\hline & Frequency & Percent & Valid Percent & $\begin{array}{c}\text { Cumulative } \\
\text { Percent }\end{array}$ \\
\hline Agree & 5 & 25,0 & 25,0 & 25,0 \\
Valid & 1 & 5,0 & 5,0 & 30,0 \\
stronglyagree & 2 & 10,0 & 10,0 & 40,0 \\
undecided & 12 & 60,0 & 60,0 & 100,0 \\
disagree & 20 & 100,0 & 100,0 & \\
Total & & & \\
\hline
\end{tabular}

Table 10 clarifies that most students (12 out of 20) said that do not feel embarrassed when they make mistakes in their English class, whereas only 5 others said they did. Besides, 2 more students were not sure if they feel embarrassed once they make mistakes in the presence of their classmates. 
Table 11: I always think that others are better than me

\begin{tabular}{|l|r|r|r|r|}
\hline & Frequency & Percent & Valid Percent & $\begin{array}{c}\text { Cumulative } \\
\text { Percent }\end{array}$ \\
\hline agree & 6 & 30,0 & 30,0 & 30,0 \\
Valid disagree & 3 & 15,0 & 15,0 & 45,0 \\
undecided & 7 & 35,0 & 35,0 & 80,0 \\
stronglydisagree & 4 & 20,0 & 20,0 & 100,0 \\
Total & 20 & 100,0 & 100,0 & \\
\hline
\end{tabular}

Table 11 reveals that students have different opinions about this statement. While 6 of them believe that other students are better than them, 7 others did not agree at all, and 4 other ones showed strong disagreement with the statement. Only 3 students were undecided about their opinions.

Table 12: Ifeel upset when my teacher keeps correcting me all the time

\begin{tabular}{|c|c|c|c|c|c|}
\hline & & Frequency & Percent & Valid Percent & $\begin{array}{c}\text { Cumulative } \\
\text { Percent }\end{array}$ \\
\hline \multirow{5}{*}{ Valid } & agree & 8 & 40,0 & 40,0 & 40,0 \\
\hline & stronglyagree & 8 & 40,0 & 40,0 & 80,0 \\
\hline & undecided & 2 & 10,0 & 10,0 & 90,0 \\
\hline & disagree & 2 & 10,0 & 10,0 & 100,0 \\
\hline & Total & 20 & 100,0 & 100,0 & \\
\hline
\end{tabular}

Table 12 demonstrates that almost all students do not like the fact that the teacher keeps correcting them all the time. 8 of them expressed agreement and 8 others chose strong agreement. Only 2 students said they disagree, and 2 others were not sure about their responses.

Table 13: I feel confident when I speak in my English class

\begin{tabular}{|c|c|c|c|c|c|}
\hline & & Frequency & Percent & Valid Percent & $\begin{array}{c}\text { Cumulative } \\
\text { Percent }\end{array}$ \\
\hline \multirow{5}{*}{ Valid } & agree & 11 & 55,0 & 55,0 & 55,0 \\
\hline & stronglyagree & 3 & 15,0 & 15,0 & 70,0 \\
\hline & undecided & 3 & 15,0 & 15,0 & 85,0 \\
\hline & disagree & 3 & 15,0 & 15,0 & 100,0 \\
\hline & Total & 20 & 100,0 & 100,0 & \\
\hline
\end{tabular}

Table 13 illustrates that more than half of the students (11 out of 20) demonstrated that they felt confident when they spoke in the English class, and 3 others revealed that that they felt highly confident. Only 3 students said they did not feel confident speaking in their English class and 3 others were undecided about whether they felt confident or not. 
Table 14: I feel excited to speak in my English class

\begin{tabular}{|l|r|r|r|r|}
\hline & Frequency & Percent & Valid Percent & $\begin{array}{c}\text { Cumulative } \\
\text { Percent }\end{array}$ \\
\hline agree & 10 & 50,0 & 50,0 & 50,0 \\
stronglyagree & 4 & 20,0 & 20,0 & 70,0 \\
Valid undecided & 4 & 20,0 & 20,0 & 90,0 \\
& 2 & 10,0 & 10,0 & 100,0 \\
disagree & 20 & 100,0 & 100,0 & \\
Total & & & & \\
\hline
\end{tabular}

Table 14 shows that most of the students felt excited to speak English in class. In this regard, 10 of them said they agree with the statement, and 4 others expressed strong agreement. Only 2 students did not feel excited to talk in the classroom, and 4 others were not sure about their opinions.

\section{FINDINGS AND DISCUSSION}

As shown in tables 1 through 14, the relationship between anxiety and foreign language learning is obviously close. It affects most students in particular classroom educational areas, but does not impact others in other instructional situations. Students' level of anxiety differs from one to another depending on their English language proficiency and their psychological state of mind. As explained above, students generally strive for acceptance among their peers (Stevick, 1989). This is why a lot of them, as shown in table 12, feel anxious and stressed when the teacher keeps correcting them all the time. It creates a feeling of anxiety among them because it touches their image, which may push them to exempt from speaking at all.

Additionally, many students appear to have a permanent feeling of test anxiety as illustrated in table 8 . This is one of the types of anxiety that was mentioned in Horwitz et al. and in several other researchers such as Young (1986), Gardner (1987), Skehan (1991) and Ganschow (1996). This is one of the highest levels of anxiety since it is constant and since it stays for a long duration; from the beginning of the foreign language course to the end. The more the test closes in on students, the more anxious they become.

However, in other classroom situations, as shown in tables $10,13 \& 14$, most students do not feel insecure or embarrassed about making mistakes. They also feel confident and excited to talk in their EFL class, because their attitude towards EFL in Morocco is highly positive, (Buckner, 2011).This perception is enhanced by a feeling to compensate forthe Moroccan students' overall weakness in French level of proficiency. This is why they find
English as another alternative to make up for their low achievement in French.

\section{CONCLUSION}

This study reveals that there is a close relationship between anxiety and foreign language learning. It is an affective factor that influences students' communication in class, their desire to participate and their willingness to learn the foreign language altogether.

\section{REFERENCES}

[1] Bellocchi, A., Quigley, C., \& Otrel-Cass, C. (2017). Exploring emotions, aesthetic and wellbeing in science education research. Switzerland: Springer.

[2] Chemi, T., Grams, S. D., \& Lund, B. (Eds.). (2017). Innovative pedagogy: a recognition of emotions and creativity in education. Rotterdam: Sense Publishers.

[3] Creswell, J. (2012). Educational research: planning, conducting, and evaluating quatitative and qualitative research. Boston: Pearson.

[4] Curran, C. A. (1972). Community language learning. Washington.

[5] Day, C., \& Lee, J. C.-K. (2011). New understandings of teacher's work: emotions and educational change. London: Springer.

[6] Dolly, J. Y. (1986). The relashionship between anxiety and foreign language oral proficiency ratings. Foreign Language Annals, 19(5), 439-445.

[7] Dornyei, Z. (2001). Motivational strategies in the language clasroom. New York: Cambridge University Press.

[8] Dulay, H. C., Burt, M. K., \&Krashen, S. D. (1982). Language two. New York: Oxford University Press.

[9] Gardner, R., \& Lambert, W. (1959). Motivational variables in second-language acquisition. Canadian Journal of Psychology, 13(4), 266-272. 
[10] Gardner, R. (1985). Social psychology and seond language learning: the role of attittudes and motivation. London: Edward Arnold.

[11] Gardner, R. (1987). The role of anxiety in second language performance of language dropouts. Research Bulletin (657).

[12] Gumperz, J. J., \& Hymes, D. H. (1972). Directions in sociolinguistics: The ethnography of communication. New York: Holt, Rinehart and Winston.

[13] Habrat, A. (2018). The role of self-esteem in foreign language learning and teaching. Switzerland: Springer International Publishing AG.

[14] Horwitz, E. K., Horwitz, M. B., \& Cope, J. (1986). Foreign language classroom anxiety. The Modern Language Journal, $70(2), 125-132$.

[15] Jane, A., (2006). Comment les facteurs affectifs influencent-ils l'apprentissage d'une langue étrangère [How do affective factors influence foreign language learning]? Ela. Études de linguistique appliquée, 4 / 144, p. 407-425.

[16] Krashen, S. D. (1982). Principles and practice in second language acquisition. Oxford: Pergamon Press.

[17] Lozanov, G. (2005). Suggestology and oulines of suggestopedy. London: Routledge.

[18] Lund, B., \& Chemi, T. (Eds.). (2015). Dealing with emotions: a pedagogical challenge to innovative learning. Rotterdam: Sense Publishers.

[19] Mowrer, R., \& Klein, S. (2001). Handbook of contemporary learning theories. New Jersey: Lawrence Erlbaum Associates.

[20] Puchta, H., \& Schratz, M. (1992). Teaching teenagers. Longman Publishing Group.

[21] Skehan, P. (1991). Individual differences in second language learning. Studies in second Stevick, W. E. (1981). Teaching languages : a way and ways. MA: Newbury House Publishers. language acquisition, 1-25.

[22] Stevick, W. E. (1989). Success with foreign languages: seven who achieved it and what worked for them. London: Prentice Hall.

[23] Vygotsky, L., 1986. Thought And Language. 1st ed. Cambridge, MA: MIT Press.

[24] Young, D. J. (1986). The Relashionship between Anxiety and Foreign Language Oral Proficiency Ratings. Foreign Language Annals, 19(5), 439-445. 